\title{
Perbandingan Pemberian Susu Kedelai Bubuk dan Susu Kedelai Rumah Tangga terhadap Glukosa Darah Puasa pada Tikus Diabetes Melitus Hasil Induksi Aloksan Monohidrat
}

\author{
Ramon Khrisna, ${ }^{1}$ H. R. Muchtan Sudjatno, ${ }^{2}$ Abdullah Firmansah ${ }^{3}$ \\ ${ }^{1}$ Departemen Kependidikan Rumah Sakit Mata Cicendo; ${ }^{2}$ Departemen Farmakologi dan Terapi, \\ ${ }^{3}$ Departemen Ilmu Gizi Medik Fakultas Kedokteran Universitas Padjadjaran- \\ Rumah Sakit Dr. Hasan Sadikin, Bandung
}

\begin{abstract}
Abstrak
Berbagai penelitian menemukan bahwa kedelai dan produk olahannya memiliki banyak manfaat terhadap berbagai kelainan metabolisme, salah satunya terhadap diabetes melitus (DM). Tujuan penelitian ini adalah untuk mengetahui dan membandingkan penurunan kadar glukosa darah puasa sesudah pemberian susu kedelai bubuk dan susu kedelai rumah tangga pada tikus DM hasil induksi aloksan. Penelitian ini dilakukan di Departemen Farmakologi Klinik RS Dr. Hasan Sadikin Bandung periode Oktober-Desember 2008 dengan metode eksperimental di laboratorium, menggunakan 30 ekor tikus yang dibagi secara acak dalam lima kelompok, salah satunya kelompok kontrol positif. Kadar glukosa darah puasa (GDP) masing-masing kelompok diperiksa setelah 14 hari perlakuan. Hasil penurunan kadar GDP rata-rata tertinggi adalah pada kelompok tikus yang mendapatkan susu kedelai rumah tangga $2 \mathrm{kali} / \mathrm{hari}$, yaitu sebesar 297,67 mg/dL, diikuti kelompok yang mendapatkan susu kedelai bubuk $2 \mathrm{kali} / \mathrm{hari}$ (270,17 mg/dL), kelompok yang mendapatkan susu kedelai bubuk 3 kali/hari (232,67 mg/dL), dan kelompok yang mendapatkan susu kedelai rumah tangga sebanyak $3 \mathrm{kali} / \mathrm{hari}(178 \mathrm{mg} / \mathrm{dL})$, sedangkan hasil penurunan kadar GDP rata-rata kontrol positif adalah 16,17 mg/dL. Hasil penurunan kadar GDP rata-rata kelompok perlakuan berbeda signifikan terhadap kelompok kontrol positif $(\mathrm{p}=0,003)$, namun tidak terdapat perbedaan penurunan kadar GDP yang signifikan antara masing-masing kelompok perlakuan $(\mathrm{p}=0,425)$. Simpulan, kedua jenis susu kedelai, baik susu kedelai bubuk maupun susu kedelai rumah tangga dapat menurunkan kadar GDP pada tikus DM hasil induksi aloksan, namun tidak terdapat perbedaan antara pemberian susu kedelai bubuk dan susu kedelai rumah tangga. Frekuensi pemberian kedua jenis susu kedelai tidak memberikan perbedaan penurunan glukosa darah.
\end{abstract}

[MKB. 2011;43(2):98-104].

Kata kunci: Glukosa darah, susu kedelai bubuk, susu kedelai rumah tangga, tikus diabetes melitus

\section{The Comparison of Powdered Soymilk and Domestic Soymilk Administration on Fasting Blood Glucose Level on Induced Diabetic Melitus Rats Aloxan Monohydrate}

\begin{abstract}
Several researches had proven that soybean and its processed goods have many benefits for several metabolism disorders, one of which is diabetes mellitus (DM). The objective of this research was to determine and compare the decrease in fasting blood glucose level after administration of powdered soymilk to domestic soymilk which was injected into diabetic rats caused by aloxan injection. This research study was conducted in Farmacology Clinic Department Dr. Hasan Sadikin Hospital Bandung on October-December 2008, with as a randomized, positivecontrolled clinical trial. Thirty mice were randomly divided into 5 groups, one of which was a control group. Fasting blood glucose (FBG) level from each group were measured after 14 days of soymilk administration. The group which was administered domestic soymilk twice daily had the highest mean decrease of FBG level $(297.67 \mathrm{mg} /$ $\mathrm{dL})$, followed by the group powdered soymilk twice daily $(270.17 \mathrm{mg} / \mathrm{dL})$, the group with powdered soymilk three times daily $(232.67 \mathrm{mg} / \mathrm{dL})$, and the group with domestic soymilk three times daily $(178 \mathrm{mg} / \mathrm{dL})$, meanwhile the positive-controlled group had mean decrease of FBG level as $16,67 \mathrm{mg} / \mathrm{dL}$. The result was significant compared to positive-controlled group $(p=0.003)$. However, the difference between each group was not significant $(p=0.425)$. It is concluded that two types of soymilk, powdered and domestic, decrease the FBG level in diabetic rats, however, the difference between the two types are insignificant. The frequency of administration of the two types of soymilk also do not give difference in decreasing the blood glucose level. [MKB. 2011;43(2):98-104].
\end{abstract}

Key words: Blood glucose level, diabetic mellitus rat, domestic soymilk, powdered soymilk Korespondensi: Ramon Khrisna, dr., Departemen Kependidikan Rumah Sakit Cicendo, jalan Cicendo 4 Bandung, telepon (022)92106188, mobile08122371588,e-mail:khrisna88@yahoo.com 


\section{Pendahuluan}

Berbagai penelitian epidemiologi menunjukkan kecenderungan peningkatan angka insidensi dan prevalensi diabetes melitus tipe-2 (DMT2) di berbagai penjuru dunia. Untuk Indonesia, WHO memprediksi kenaikan jumlah penderita dari 8,4 juta pada tahun 2000 menjadi sekitar 21,3 juta pada tahun $2030{ }^{1}$

Menurut American Diabetes Association (ADA), diabetes melitus (DM) merupakan suatu kelompok penyakit metabolik dengan karakteristik hiperglikemia yang terjadi karena kelainan sekresi insulin, kerja insulin, atau keduaduanya. $^{2}$ Penurunan fungsi ini berlangsung secara progresif serta berjalan terus menerus dan bila progresif akan memperburuk pengendalian glukosa darah dan hal ini tetap terjadi walaupun diberikan pengobatan konvensional yang intensif. United Kingdom Prospective Diabetes Study (UKPDS) membuktikan bahwa kontrol glikemik dengan intensif sangat berhubungan erat dengan keuntungan klinis pada DMT2. Kematian yang berhubungan dengan DM sebesar $21 \%$, infark miokardium 14\%, komplikasi mikrovaskular 37\%, dan penyakit pembuluh darah perifer $43 \%$. ${ }^{3}$

Penelitian mengenai efek berbagai macam bahan makanan, obat-obatan, maupun makanan tambahan terhadap penyakit DM telah banyak dilakukan. Salah satunya adalah kedelai dan produk olahannya, termasuk susu kedelai. Jayagopal dkk. ${ }^{4}$ menyatakan bahwa pemberian suplemen protein kedelai sebesar $30 \mathrm{~g} / \mathrm{hari}$ dengan kadar isoflavon (suatu senyawa flavonoid yang memiliki sifat antioksidan) sebesar 132 $\mathrm{mg}$ /hari dapat menurunkan resistensi insulin sebesar $8,09 \%$ pada wanita postmenopause dengan DMT2, tetapi tidak berpengaruh pada kadar glukosa darah puasa. Liu dkk. ${ }^{5}$ menyatakan bahwa genistein, isoflavon yang banyak terdapat dalam kedelai dapat meningkatkan stimulasi insulin pada sel $\beta$ pankreas sebesar $50 \% .{ }^{5}$ Barclay $^{6}$ menyatakan bahwa dengan pemberian protein kedelai sebanyak $0,8 \mathrm{~g} / \mathrm{kgBB}$ dapat menurunkan kadar gula darah puasa rata-rata sebesar $18+3$ $\mathrm{mg} / \mathrm{dL}$ pada penderita DMT2, sedangkan bila tidak diberi kedelai meningkat sebesar $11 \mathrm{mg} /$ dL. Bhatena dan Velasquez ${ }^{7}$ menyatakan dengan penambahan bubuk kedelai pada makanan tikus DM dapat menurunkan glukosa plasma, kolesterol, dan kadar lipid. Sementara itu, Lavigne dkk. ${ }^{8}$ mengemukakan bahwa pemberian protein kedelai dapat memperbaiki toleransi glukosa dan sensitivitas isulin pada tikus.

Keadaan hiperglikemia dapat memperberat keadaan resistensi insulin yang akhirnya dapat memperburuk DM dan menimbulkan berbagai komplikasi. Selain terapi konvensional pada penderita DM, perlu dipertimbangkan pemberian makanan tambahan yang dapat mengontrol kadar glukosa darah. Beberapa penelitian menunjukkan bahwa susu kedelai dan isoflavon yang banyak terdapat dalam kedelai berperan untuk metabolisme glukosa darah. Susu kedelai banyak beredar di masyarakat, baik dalam bentuk cair maupun dalam bentuk bubuk. Susu kedelai bubuk buatan pabrik yang mengalami proses fortifikasi dianggap memiliki pengaruh yang lebih baik pada berbagai proses metabolisme, termasuk pada penyakit DM. Berdasarkan hal di atas, maka penelitian ini dilakukan untuk membandingkan kadar glukosa darah puasa tikus DM hasil induksi aloksan yang diberikan susu kedelai bubuk dan susu kedelai rumah tangga.

\section{Metode}

Subjek penelitian adalah 30 ekor tikus jantan galur Wistar berumur sekitar 2-3 bulan, dibagi secara acak ke dalam 5 kelompok. Adapun kriteria inklusi adalah: sehat, bobot badan awal 150-200 gram, dan kadar glukosa darah puasa (GDP) setelah induksi $>135 \mathrm{mg} / \mathrm{dL}$, sedangkan kriteria eksklusi bila terlihat sakit selama adaptasi. Sebelum penelitian dimulai, hewan coba diadaptasikan dengan suasana laboratorium selama tujuh hari, diberi makan dan minum air ad libitum.

Penelitian ini merupakan penelitian eksperimental di laboratorium dengan menggunakan tikus jantan galur Wistar sebagai hewan coba. Desain penelitian yang digunakan adalah rancangan acak lengkap (complete randomized design). Pada penelitian ini dilakukan pemberian dua jenis susu kedelai pada tikus tersebut untuk membandingkan kadar glukosa darah puasa pada tikus diabetes melitus hasil induksi aloksan.

Tikus diadaptasikan terlebih dahulu selama 7 hari di Laboratorium Bagian Farmakologi Klinik Rumah Sakit Dr. Hasan Sadikin Bandung periode Oktober-Desember 2008, kemudian baru diberikan perlakuan. Induksi diabetes melitus dilakukan pada 30 tikus yang menjadi subjek penelitian dengan menyuntikkan aloksan monohidrat secara subkutan pada bagian perut tikus dengan dosis $125 \mathrm{mg} / \mathrm{kgBB}$. Setelah 48 jam, semua tikus yang diinduksi kemudian diperiksa kadar glukosa darah puasanya (GDP). Tikus yang dipilih untuk percobaan ini adalah yang memiliki kadar glukosa $>135 \mathrm{mg} / \mathrm{dL}$. Semua tikus dibagi dalam lima kelompok perlakuan sebagai berikut: kelompok I sebagai kontrol positif, kelompok II mendapatkan $5 \mathrm{~mL}$ susu kedelai bubuk sebanyak 3 kali/hari, kelompok III mendapatkan $5 \mathrm{~mL}$ susu kedelai rumah tangga sebanyak $3 \mathrm{kali} / \mathrm{hari}$, kelompok IV mendapatkan $5 \mathrm{~mL}$ susu kedelai 
bubuk sebanyak 2 kali/hari, dan kelompok V mendapatkan $5 \mathrm{~mL}$ susu kedelai rumah tangga sebanyak 2 kali/hari.

Untuk memeriksa kadar glukosa darah puasa digunakan alat pengukur kadar glukosa darah kapiler GlucoDr Super Sensor ${ }^{\mathrm{TM}}$ dari Allmedicus Co., Ltd. (glukotes), lanset, dan kapas. Darah kapiler diambil dari bagian ekor tikus dan diteteskan ke carik glukotes, kemudian carik tersebut dimasukkan ke dalam bagian tertentu dari alat glukotes. Hasil dapat dilihat pada layar dalam waktu kurang lebih 10 detik, nilai yang tercantum di layar adalah kadar glukosa darah dalam $\mathrm{mg} / \mathrm{dL}$.

Analisis statistik mempergunakan paired t-test dan one way analysis of variance (ANOVA). Apabila hasil analisis varian menunjukkan adanya perbedaan yang nyata, maka dilanjutkan dengan uji berganda Duncan dengan derajat kepercayaan 95\% $(\mathrm{p} \leq 0,05)$. Analisis dilakukan dengan menggunakan program SPSS for Windows versi 11.0.

\section{Hasil}

Hasil pengukuran kadar gula darah puasa (GDP) pada hewan coba yang telah mendapatkan perlakuan selama 14 hari dapat dilihat pada Tabel 1.

Hasil pengukuran kadar GDP tikus yang telah diinduksi menjadi hiperglikemia dibandingkan pada hari ke-14 setelah perlakuan antara kelompok I (kontrol positif), kelompok II yang diberi susu kedelai bubuk 3 kali sehari, kelompok III yang diberi susu kedelai rumah tangga 3 kali sehari, kelompok IV yang diberi susu kedelai bubuk 2 kali sehari, dan kelompok $\mathrm{V}$ yang diberi susu kedelai rumah tangga 2 kali sehari.

Pada perhitungan paired t-test didapatkan kelompok I memiliki $p>0,05$, hal ini menyatakan tidak terjadi perbedaan yang signifikan antara hasil pengukuran GDP pascainduksi dan setelah 14 hari perlakuan. Pada kelompok II, kelompok III, kelompokIV, dan kelompokVmemilikinilaip $<0,05$, hal ini menyatakan terdapat perbedaan signifikan antara hasil pengukuran GDP pascainduksi dan setelah 14 hari perlakuan.

Pada Gambar 1 terlihat bahwa pada kelompok II, III, IV, V terdapat perbedaan yang signifikan antara kadar GDP rata-rata pascainduksi dan GDP setelah 14 hari perlakuan. Hal ini menunjukkan terdapat penurunan kadar GDP yang berarti akibat perlakuan yang diberikan.

Berdasarkan uji paired t-test yang telah dilakukan terdapat perbedaan kadar GDP yang signifikan antara pascainduksi dan setelah perlakuan selama 14 hari pada semua kelompok perlakuan (kelompok II, III, IV, V).

Selanjutnya peneliti akan menguji pada kelompok perlakuan yang mana didapatkan penurunan GDP yang terbaik di antara kelompok II, III, IV, dan kelompok V, maka akan dibandingkan penurunan kadar GDP setelah 14 hari perlakuan dengan uji statistik oneway ANOVA sebagaimana yang disusun dalam tabel distribusi penurunan kadar GDP rata-rata setiap kelompok (Tabel 2).

Pada Tabel 2 sesuai dengan uji statistik oneway ANOVA didapatkan nilai $\mathrm{p}=0,045$ dan hal ini membuktikan bahwa terdapat perbedaan yang signifikan secara statistik penurunan kadar GDP rata-rata di antara kelima kelompok tersebut.

Setelah 14 hari perlakuan terdapat penurunan kadar GDP rata-rata mulai dari yang tertinggi hingga yang terendah berturut-turut adalah sebagai berikut: kelompok V, IV, II, dan III masing-masing sebesar 297,67 mg/dL, 270,17 mg/dL, 232,67 mg/ dL, dan $178 \mathrm{mg} / \mathrm{dL}$, sedangkan pada kelompok I didapatkan penurunan GDP sebesar 16,17 mg/dL.

Perbandingan distribusi penurunan kadar GDP rata-rata akan tampak lebih jelas pada Gambar 2.

Uji statistik yang selanjutnya dilakukan adalah uji berganda Duncan untuk mengetahui kelompok mana yang mempunyai perbedaan ratarata yang berbeda secara signifikan sebagaimana disajikan dalam Tabel 3.

Berdasarkan Tabel 3 dapat dilihat bahwa terdapat 2 kelompok subset untuk kelima kelompok perlakuan. Kelompok yang tergolong di bawah satu subset tidak mempunyai perbedaan secara signifikan.

Dalam subset 1 terdapat kelompok V, IV, II, dan kelompok III. Ini menunjukkan bahwa keempat kelompok perlakuan tersebut (kelompok V, IV, II, III) dapat menurunkan kadar GDP dengan penurunan terbesar pada kelompok V, yaitu pemberian susu kedelai rumah tangga sebanyak 2 kali/hari.

Dalam subset 2 hanya terdapat kelompok I yang merupakan model hewan diabetes melitus tanpa perlakuan/terapi. Jika kelompok I dibandingkan dengan kelompok perlakuan lainnya, maka akan tampak penurunan kadar GDP yang berbeda secara signifikan, karena kelompok I terletak pada subset yang berbeda dengan kelompok perlakuan lainnya.

Perbandingan antar kelompok subset dapat dinilai secara signifikan bila kelompok dalam satu subset tidak mengandung kelompok yang sama dengan kelompok subset yang lain, sebagaimana berikut ini: Kelompok V, IV, II, dan III adalah berbeda secara signifikan dengan kelompok I, karena kelompok V, IV, II, dan III hanya terletak pada subset 1 . Hal ini berarti bahwa penurunan kadar GDP setelah perlakuan selama 14 hari adalah signifikan pada kelompok V, IV, II, dan III bila dibandingkan dengan kelompok I. Kelompok 
Tabel 1 Data Hasil Pengukuran Kadar Glukosa Darah Puasa

\begin{tabular}{|c|c|c|c|c|c|c|c|}
\hline Kelompok & $\begin{array}{c}\text { Tikus } \\
\text { No. }\end{array}$ & $\begin{array}{c}\text { Bobot } \\
\text { Badan } \\
\text { Awal (g) }\end{array}$ & $\begin{array}{l}\text { GDP Pra- } \\
\text { induksi } \\
(\mathrm{mg} / \mathrm{dL})\end{array}$ & $\begin{array}{c}\text { GDP } \\
\text { Pasca- } \\
\text { induksi } \\
(\mathrm{mg} / \mathrm{dL})\end{array}$ & $\begin{array}{c}\text { GDP } \\
\text { 14 Hari } \\
\text { Perlakuan } \\
\text { (mg/dL) }\end{array}$ & $\begin{array}{l}\text { Penurunan } \\
\text { GDP Rata- } \\
\text { rata }(\bar{x}) \\
\text { (SD) }\end{array}$ & $\begin{array}{c}\text { Bobot } \\
\text { Badan } \\
\text { Akhir (g) }\end{array}$ \\
\hline \multirow{6}{*}{ I } & 1 & 154 & 79 & 367 & 294 & \multirow{6}{*}{$\begin{array}{c}-16,67 \\
(38,61)\end{array}$} & 151 \\
\hline & 2 & 153 & 59 & 203 & 204 & & 150 \\
\hline & 3 & 154 & 79 & 219 & 198 & & 155 \\
\hline & 4 & 154 & 82 & 218 & 197 & & 152 \\
\hline & 5 & 170 & 70 & 220 & 192 & & 165 \\
\hline & 6 & 153 & 54 & 339 & 384 & & 155 \\
\hline \multirow{6}{*}{ II } & 1 & 152 & 98 & 317 & 182 & \multirow{6}{*}{$\begin{array}{l}-232,67 \\
(96,16)\end{array}$} & 150 \\
\hline & 2 & 150 & 98 & 234 & 88 & & 152 \\
\hline & 3 & 154 & 101 & 282 & 77 & & 157 \\
\hline & 4 & 155 & 98 & 327 & 114 & & 150 \\
\hline & 5 & 223 & 68 & 617 & 293 & & 208 \\
\hline & 6 & 201 & 75 & 615 & 242 & & 187 \\
\hline \multirow{6}{*}{ III } & 1 & 150 & 99 & 253 & 143 & \multirow{6}{*}{$-178(78,12)$} & 157 \\
\hline & 2 & 163 & 94 & 408 & 290 & & 160 \\
\hline & 3 & 150 & 68 & 396 & 96 & & 150 \\
\hline & 4 & 166 & 104 & 414 & 170 & & 159 \\
\hline & 5 & 163 & 95 & 355 & 182 & & 158 \\
\hline & 6 & 150 & 70 & 289 & 166 & & 158 \\
\hline \multirow{6}{*}{ IV } & 1 & 155 & 95 & 563 & 183 & \multirow{6}{*}{$\begin{array}{c}-270,17 \\
(192,06)\end{array}$} & 150 \\
\hline & 2 & 156 & 103 & 245 & 105 & & 154 \\
\hline & 3 & 150 & 87 & 266 & 95 & & 152 \\
\hline & 4 & 173 & 85 & 258 & 126 & & 165 \\
\hline & 5 & 169 & 111 & $\mathrm{Hi}$ & 285 & & 157 \\
\hline & 6 & 160 & 95 & 289 & 106 & & 164 \\
\hline \multirow{6}{*}{ V } & 1 & 192 & 99 & 346 & 63 & \multirow{6}{*}{$\begin{array}{c}-297,67 \\
(118)\end{array}$} & 188 \\
\hline & 2 & 186 & 84 & 391 & 190 & & 182 \\
\hline & 3 & 165 & 73 & 489 & 147 & & 160 \\
\hline & 4 & 175 & 85 & 384 & 124 & & 172 \\
\hline & 5 & 150 & 111 & 575 & 65 & & 151 \\
\hline & 6 & 151 & 95 & 305 & 115 & & 156 \\
\hline
\end{tabular}

Keterangan:

Kelompok I: Kontrol positif (induksi aloksan + pelet, air ad libitum)

Kelompok II: Induksi aloksan + susu kedelai bubuk $5 \mathrm{~mL}$, diberikan 3 kali sehari

Kelompok III: Induksi aloksan + susu kedelai rumah tangga $5 \mathrm{ml}$, diberikan 3 kali sehari

Kelompok IV: Induksi aloksan + susu kedelai bubuk $5 \mathrm{~mL}$, diberikan 2 kali sehari

Kelompok V: Induksi aloksan + susu kedelai rumah tangga $5 \mathrm{~mL}$, diberikan 2 kali sehari

V, IV, II, dan III berada pada satu subset yang sama, yaitu subset 1 . Ini berarti bahwa penurunan GDP darah pada kelompok V, IV, II, dan III adalah sama/tidak memiliki perbedaan yang signifikan dengan penurunan GDP rata-rata, terbesar terdapat pada kelompok V, yaitu 297,67 $\mathrm{mg} / \mathrm{dL}$.

\section{Pembahasan}

Pada hasil pengukuran kadar GDP, sebagian besar hewan coba pada tiap-tiap kelompok menunjukkan penurunan setelah perlakuan selama 14 hari. Hal tersebut menunjukkan bahwa susu kedelai terbukti dapat memperbaiki kadar glukosa darah pada tikus 


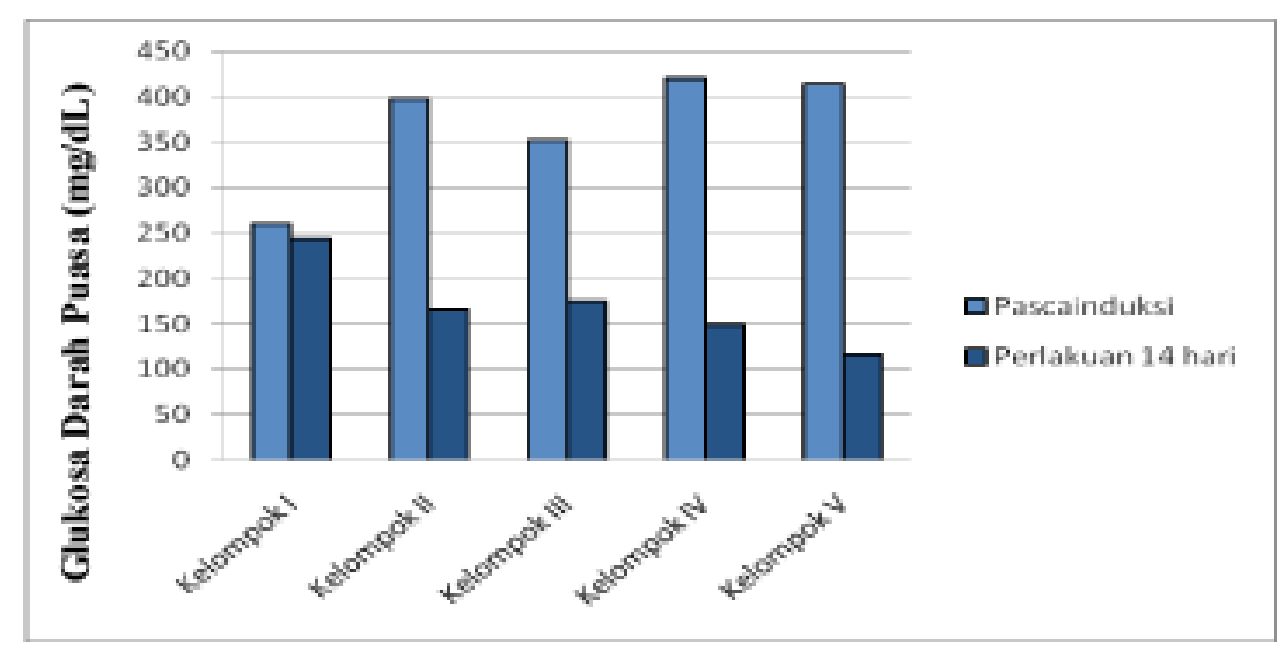

\section{Gambar 1 Distribusi Glukosa Darah Puasa/GDP Rata-rata (mg/dL) Pascainduksi dan setelah 14 Hari Perlakuan}

Tabel 2 Distribusi Penurunan Kadar Glukosa Darah Puasa/GDP Rata-rata (mg/dL)

\begin{tabular}{cccc}
\hline Kelompok & Rata-rata & SD & Nilai p \\
\hline I & $-16,17$ & 38,61 & \\
II & $-232,67$ & 96,16 & 0,045 \\
III & $-178,00$ & 78,12 & \\
IV & $-270,17$ & 192,06 & 118,00 \\
V & $-297,67$ &
\end{tabular}

Keterangan:

Kelompok I: Kontrol positif (induksi aloksan + pelet, air ad libitum)

Kelompok II: Induksi aloksan + susu kedelai bubuk $5 \mathrm{~mL}$, diberikan 3 kali sehari

Kelompok III: Induksi aloksan + susu kedelai rumah tangga $5 \mathrm{~mL}$, diberikan 3 kali sehari

Kelompok IV: Induksi aloksan + susu kedelai bubuk $5 \mathrm{~mL}$, diberikan 2 kali sehari

Kelompok V: Induksi aloksan + susu kedelai rumah tangga $5 \mathrm{~mL}$, diberikan 2 kali sehari

DM hasil induksi aloksan.

Menurut penelitian singkat yang dilakukan oleh Jayagopal dkk. ${ }^{4}$ selain dapat meningkatkan kontrol glukosa, pemberian kedelai juga dapat memperbaiki keadaan resistensi insulin, tetapi beberapa penelitian lain menunjukkan inkonsistensi efek kedelai dalam mengontrol kadar glukosa darah pada DM. Kandungan serat dalam kedelai diduga turut berperan dalam mengontrol kadar glukosa darah, baik dalam jangka panjang maupun dalam jangka pendek. Studi in vitro mengemukakan bahwa terdapat beberapa mekanisme kontrol glikemik oleh kedelai, di antaranya aksi inhibisi tyrosine kinase, perubahan jumlah dan afinitas reseptor insulin, fosforilasi intraselular, dan perubahan pada transpor glukosa. ${ }^{4,8-10}$

Pada penelitian ini terjadi penurunan kadar glukosa darah secara signifikan terhadap kontrol

Tabel 3 Hasil Uji Lanjut Penurunan Kadar Glukosa Darah Puasa/GDP Rata-rata (mg/dL)

\begin{tabular}{llcc}
\hline \multirow{2}{*}{ Kelompok } & N & \multicolumn{2}{c}{ Subset for alpha $=\mathbf{0 5}$} \\
\cline { 3 - 4 } & & $\mathbf{1}$ & $\mathbf{2}$ \\
\hline V & 6 & $-297,67$ & \\
IV & 6 & $-270,17$ & \\
II & 6 & $-232,67$ & $-16,17$ \\
III & 6 & $-178,00$ & \\
I & 6 & &
\end{tabular}

Kelompok I : Kontrol positif (induksi aloksan + pelet, air ad libitum)

Kelompok II: Induksi aloksan + susu kedelai bubuk $5 \mathrm{~mL}$, diberikan 3 kali sehari

Kelompok III: Induksi aloksan + susu kedelai rumah tangga $5 \mathrm{~mL}$, diberikan 3 kali sehari

Kelompok IV: Induksi aloksan + susu kedelai bubuk $5 \mathrm{~mL}$, diberikan 2 kali sehari

Kelompok V: Induksi aloksan + susu kedelai rumah tangga $5 \mathrm{~mL}$, diberikan 2 kali sehari 


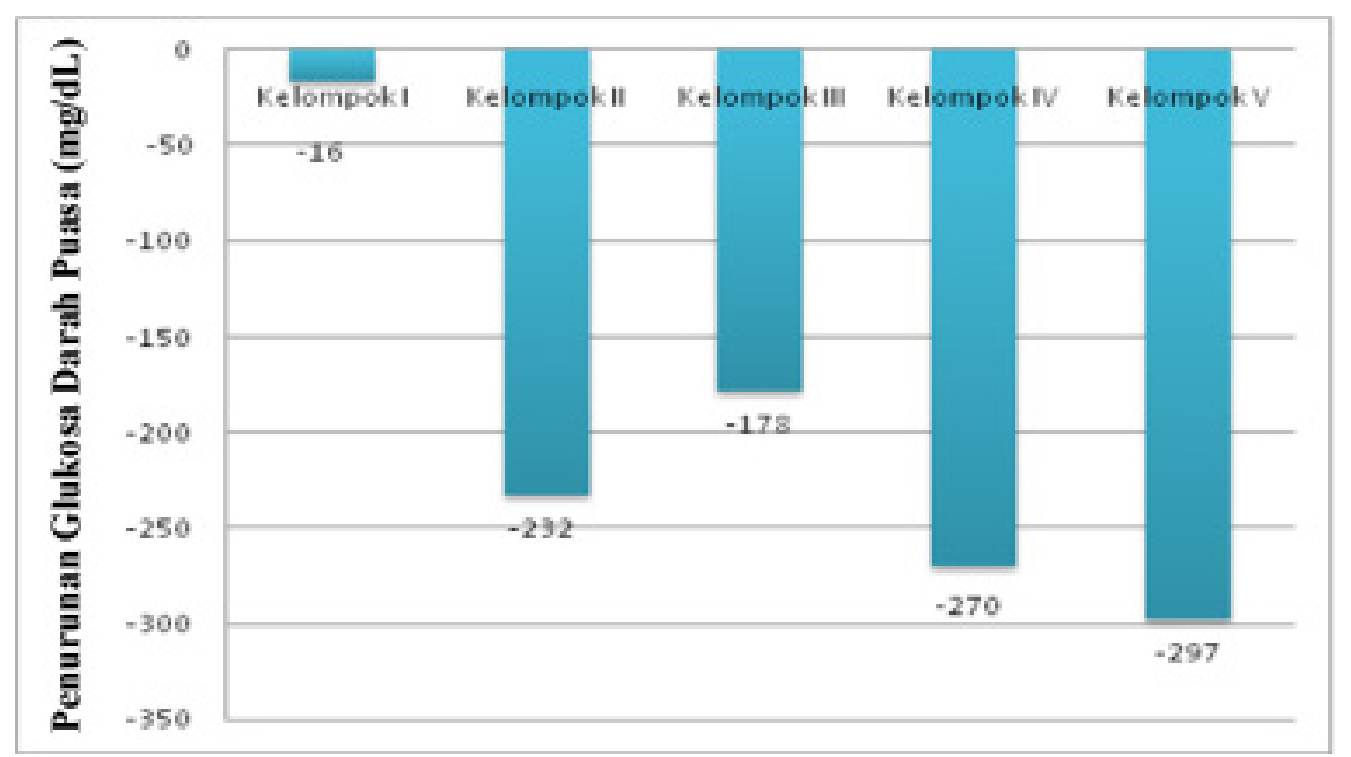
Gambar 2 Distribusi Penurunan Kadar Glukosa Darah Puasa/GDP Rata-rata (mg/dL) setelah
Perlakuan Selama 14 Hari

positif setelah hewan coba diberi perlakuan selama 14 hari berturut-turut, namun tidak diketahui apakah terdapat perbaikan keadaan resistensi insulin. Pada penelitian ini juga tidak diketahui jenis mekanisme kontrol glikemik yang terjadi, tetapi diduga otot skelet menjadi tempat aksi protein kedelai dalam menstimulasi insulin di jaringan perifer. ${ }^{8} \mathrm{Hal}$ serupa pernah dilakukan oleh Bhatena dan Velasquez ${ }^{7}$ pada tahun 2002 dengan menggunakan kedelai bubuk yang ditambahkan pada makanan tikus dan terbukti penambahan bubuk kedelai tersebut memberikan efek penurunan kadar glukosa plasma bermakna pada hewan coba yang diinduksi aloksan, namun efek penurunan GDP diperoleh pada hari ke-5 sejak perlakuan dimulai.

Perbedaan komposisi asam amino pada diet protein berpengaruh pada dinamika insulin dan kadar glukosa darah, dalam hal ini arginin yang terkandung dalam susu kedelai diduga banyak berperan dalam merangsang pengeluaran insulin dari pankreas dan meningkatkan aktivitas insulin di otot skelet. ${ }^{7,8}$

Beberapa mikronutrien pada kedelai diketahui memiliki efek menguntungkan terhadap DM, seperti kromium $(\mathrm{Cr})$ dan magnesium $(\mathrm{Mg})$ yang dapat meningkatkan aktivitas dan sensitivitas insulin. ${ }^{11}$ Jumlah mikronutrien dalam susu kedelai sangat bervariasi, bergantung pada jenis kedelai, cara, dan lokasi penanamannya. ${ }^{12}$

Pada penelitian sebelumnya mengenai efek kedelai terhadap DM, isoflavon dapat berperan sebagai inhibitor $\alpha$-glukosidase yang menghambat pengambilan glukosa oleh vili usus dan menginhibisi tyrosine kinase, ${ }^{8}$ tetapi hingga saat ini belum jelas komponen kedelai yang paling berperan dalam mengontrol kadar glukosa darah pada DM, meskipun beberapa penelitian menduga bahwa kedua komponen tersebut bekerja secara sinergis untuk mencapai hasil yang optimal. ${ }^{4-8}$ Jumlah isoflavon yang diperlukan untuk menimbulkan efek terapeutik sangat bervariasi. Pada manusia jumlah isoflavon yang diperlukan sebesar $25-150 \mathrm{mg} /$ hari, sementara dalam segelas susu kedelai kandungan isoflavon adalah $15-30 \mathrm{mg} .{ }^{13}$ Sebagai simpulan, pemberian susu kedelai bubuk maupun susu kedelai rumah tangga, terbukti menurunkan kadar GDP pada tikus diabetes melitus hasil induksi aloksan. Penurunan kadar GDP terbaik pada pemberian susu kedelai rumah tangga 2 kali/hari, yaitu 297,67 $\mathrm{mg} / \mathrm{dL}$, diikuti kelompok yang mendapatkan susu kedelai bubuk $2 \mathrm{kali} / \mathrm{hari}(270,17 \mathrm{mg} / \mathrm{dL})$, kelompok yang mendapatkan susu kedelai bubuk 3 kali/hari $(232,67 \mathrm{mg} / \mathrm{dL})$, dan kelompok yang mendapatkan susu kedelai rumah tangga $3 \mathrm{kali} / \mathrm{hari}(178 \mathrm{mg} / \mathrm{dL})$, tetapi tidak terdapat perbedaan antara pemberian susu kedelai bubuk dan susu kedelai rumah tangga. Demikian juga frekuensi pemberian kedua jenis susu kedelai tidak berbeda.

\section{Daftar Pustaka}

1. Perkumpulan Endokrinologi Indonesia (Perkeni). Konsensus pengelolaan dan pencegahan diabetes melitus tipe 2 di Indonesia. Jakarta: Perkeni; 2006.

2. Soegondo S. Penatalaksanaan diabetes melitus terpadu, Cetakan ke-2. Jakarta: Balai Penerbit FKUI; 2002. 
3. UK Prospective Diabetes Study (UKPDS) Group. Intensive blood-glucose control with sulphonylures or insulin compared with conventional treatment and risk of complications in patients with type 2 diabetes (UKPDS 33). Lancet. 1998;352:837-53.

4. Jayagopal V, Albertazzi P, Kilpatrick ES. Beneficial effect of soy phytoestrogen intake in postmenopausal women with type 2 diabetes. Diabetes Care. 2002;25:1709.

5. Liu O, Zhen W, Yang Z. Genistein acutely stimulates insulin secretion in pancreatic $\beta$-cells through a cAMP-dependent protein kinase pathway. Diabetes J. 2006;55:104350.

6. Barclay L. Soy intake may benefit patients with type 2 diabetes and nephropathy. Diabetes Care. 2008;31:648-54.

7. Bhatena SJ, Velasquez MT. Beneficial role of dietary phytoestrogen in obesity and diabetes. Am J Clin Nutr. 2002;76(6):1191-201.

8. Lavigne C, Marette A, Jaques H. Cod and soy proteins compared with casein improve glucose tolerance and insulin sensitivity in rats. Am J Physiol Endocrinol Metab. 2000;278:491-500

9. Nettleton JA, Harnack LJ, Scrafford CG. Dietary flavonoids and flavonoid-rich foods are not associated with risk of type 2 diabetes in postmenopausal women. Nutr J. 2006;136:3039-45.

10. Unger RH, Foster DW. Diabetes mellitus Dalam: Wilson JD, penyunting. Williams textbook of endocrinology. Edisi ke-10. Philadelphia: WB Saunders Company; 2000. hlm. 973-1040.

11. O'Connell BS. Select vitamins and minerals in the management of diabetes (diunduh 5 Januari 2011). Tersedia dari: http://spectrum. diabetesjournals.org/cgi/full/14/3/133.

12. Russo J, Curtis S. Nutritional and health benefits of soybeans. J Nutr. 2004; 143(12):2355-78.

13. Higdon J. The clinical importance of the soy and its isoflavones. J Nutr. 2002;132(12): 3577-8. 